\title{
成長ホルモン産生下垂体腺腫に伴う下顎前突症に対する1治験例
}

\author{
福川義邦・柳澤繁孝・清水 修*
}

田辺炤博**. 石丸孝则***

\section{A case of mandibular prognathism according with pituitary adenoma producing growth hormone}

\author{
Yoshikuni Fukuyama - Shigetaka Yanagisawa - Osamu Shimizu* \\ Akihiro TANABE** - Takanori Ishimaru***
}

\begin{abstract}
We presented an outline of a surgical orthodontic correction which we performed for an acromegalic patient whose serum growth hormone $(\mathrm{GH})$ was not controlled enough after removal of pituitary adenoma.

The patient was a 35-years-old male on the first visit. Under the diagnosis of pituitary adenoma, the tumor removal was performed in September 1986. In our clinic, we performed tongue reduction on 7 June 1988 and Obwegeser-Dal Pont method on 14 March 1989, even though his serum GH was not controlled enough at that time.

In this case there were no complications during operation and postoperative period. 21 months have passed postoperatively. There has not been a relapse, and his feature and occlusal function remain in good condition.
\end{abstract}

Key words: acromegaly（末端肥大症）， mandibular prognatism（下顈前突症）， surgical orthodontics (外科的矯正術)

緒言

末端肥大症は，その大部分が脳下垂体腺腫からの成長 ホルモン（以下 GH と略す）過剩分泌に起因寸る比較 的まれな疾患である。

本症の顎顔面外科処置の時期は，原則として下垂体腺 腫に対する加療により血中 $\mathrm{GH}$ 值が正常化された後が 望むしいと思われるが，必ずしもこのような状況下で手 術が行われるとは限らず, 顔面の醜形, 高度の下䫁前 突，吹合不全の治療に際し悩まされるところである。
今回われわれは, 脳下垂体腺腫摘出後も血中 $\mathrm{GH}$ 值 がやや高值を示す末端肥大症に対して, Obwegeser-Dal Pont 法による下嵿後退術を施行し, 良好な結果が得ら れたので文献的考察を加光，その概要を報告する。

症例

患，者：35歳 男性.

初診:1987年7

主 訴: 峳合不全.

家族歴：特記事項なし。

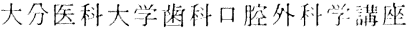

（主任：消水正嗣教授）

* 健和会大手町病院附属菌科啫療所

（所長：消水修）

**健和総合病院附属附科揨療所

(所長：田辺昭缚)

*** 山口大学医学部菌科口腔外科学講座 （主任：㙫崎文彦教授）

Department of Oral and Maxillo-Faciai Surgery, Medical College of Oita (Chief: Prof.
Masatsugu Shimizu)

* Dental Clinic of Kenwakai-Otemati Hospital (Chicf: Osamu Shimizu)

** Dental Clinic of Kenwa-General Hospital (Chief: Akihiro Tanabe)

*** Department of Oral and Maxillo-Facial Surgery, School of Medicine, Yamaguchi University (Chief: Prof. Fumihiko Shinozaki) 受付日：平成 2 年12月12日 


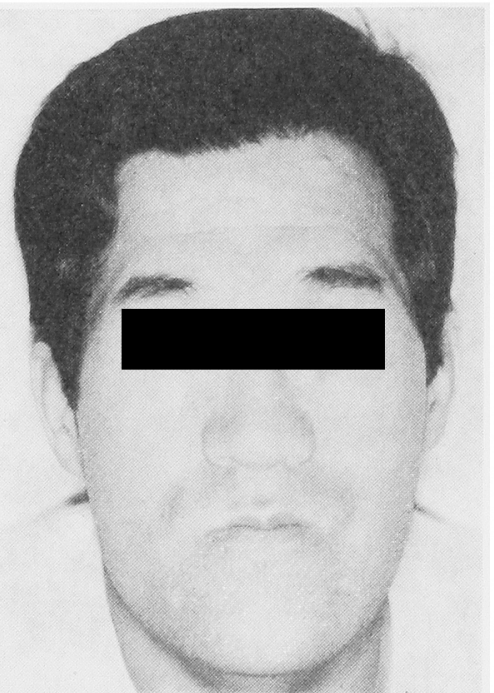

写真 1 初診時顔貌（正面）（35 歳, 男性)

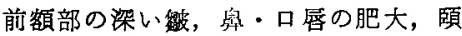
部の笑出を認める。

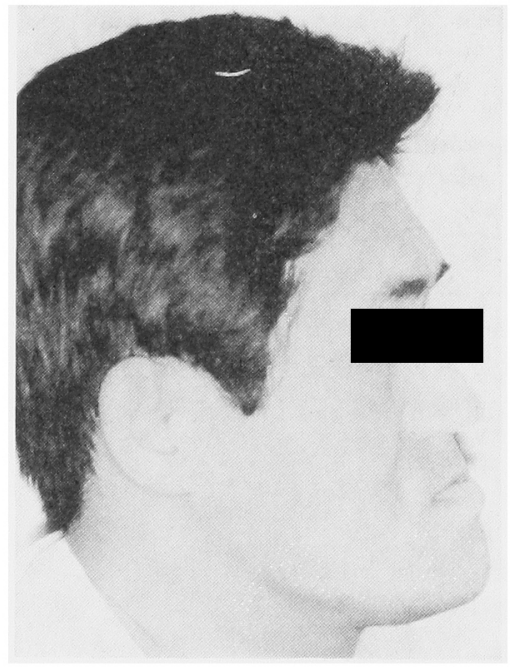

写真 2 初診時㑡貌

眉弓部の实出，下顎の前突が著しい。

\section{既往歴：特記事項なし。}

現病歴：中学時代後期より徐々に下䫇が前突し始め， 高校時代後半には上下の歯牙が全く咬合しなくなった。 1985年12月交通事故による外賃性頸部症候群，頸䯣損賃 の题いにて大分 大学 外科入院中心下垂体腺腫 が発見され，末端肥大症の診断を受けた，1986年 9 月同 科にて腺腫摘出術を受け，健和会—病院にてその後 の経過観察中，附属歯科診療所を受診した。

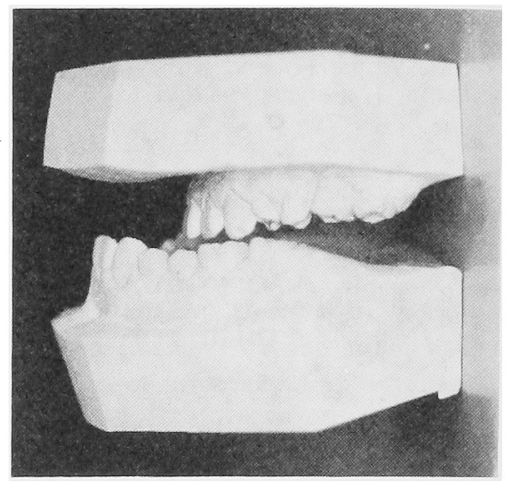

写真 3 初診時石育模型珓合状熊 上下の畨牙接低を認めず，便宜的水平 被培は一20 $\mathrm{mm}$ でめった。

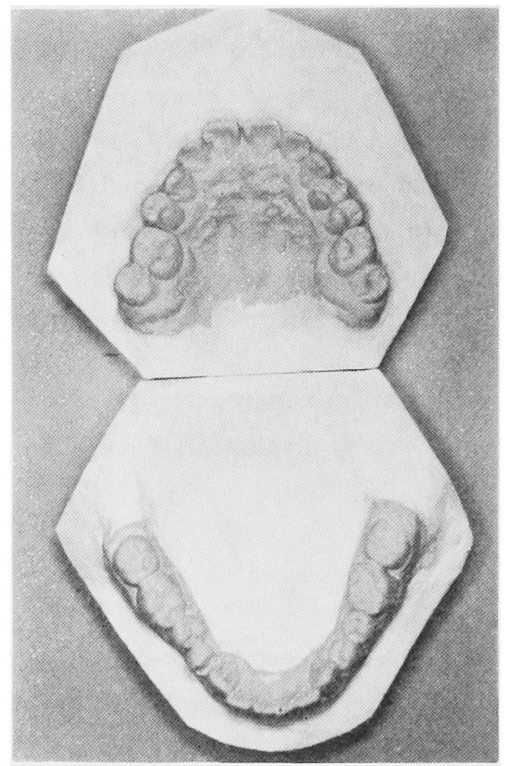

写真 4 同口腔内スタディモデル

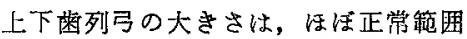
内によった。

\section{現 症}

全身所見：身長 $170 \mathrm{~cm}$, 体重 $80 \mathrm{~kg}$ ，手指，趾指は 太く丸みを帯び，手足は厚ぼったく，未端肥大症所見が 認められた。

顔貌所見：正貌はほぼ左右対称で，皮凰は粗く肥厚

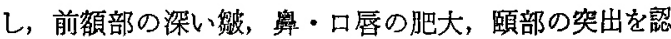
めた（写真 1)，側貌では眉马部の乫出と下䫑の前突が 著しく，末端肥大症の特街を呈していた（写真 2).

口腔内所見：舌は肥大し巨舌症を呈し，閉口安静時に は上顎歯牙の咬合面を覆っていた。 上下顎の咬合関係で は崡牙の接触を認めず，上下前齿の切端を同一水平面に 


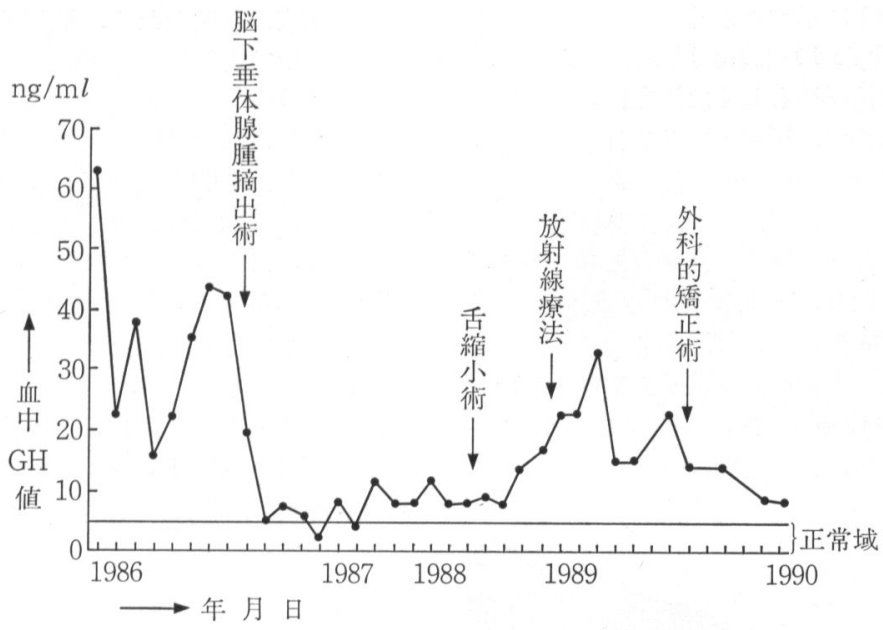

図 1 血中 $\mathrm{GH}$ の経時的変化

表 1 歯列弓の副径と長径の本報告例と文献報告 例との比較

\begin{tabular}{l|l|c|c}
\hline & 上 顎 & 下 顎 \\
\hline \multirow{4}{*}{ 歯列弓副径 } & Howes & $41.76 \pm 3.19$ & $33.97 \pm 2.56$ \\
& 大 坪 & $44.77 \pm 2.61$ & $36.26 \pm 1.99$ \\
& 山 内ら & $45.67 \pm 2.06$ & $36.30 \pm 2.23$ \\
& 本報告例 & 44.0 & 34.2 \\
\hline \multirow{5}{*}{ 齿列弓長径 } & Howes & $34.65 \pm 2.43$ & $31.28 \pm 2.38$ \\
& 大 坪 & $36.09 \pm 2.23$ & $31.91 \pm 2.10$ \\
& 山 内ら & $37.54 \pm 1.92$ & $33.34 \pm 2.34$ \\
& 本報告例 & 34.7 & 32.8 \\
\hline
\end{tabular}

単位 $(\mathrm{mm})$

揃えた際の便宜的水平被蓋は $-20 \mathrm{~mm}$ であった（写真 3).

写真 4 は初診時の口腔内スタディモデルを示す．欠損 ないし未萌出崡は $\frac{85 \mid 6}{818}$ の 5 歯であり, $\underline{76 \mid 78}$ は近心移 動し, 欠損部の空隙は認められなかった。 また, 口蓋は 高く口蓋隆起が著明であった。

表 1 は, Howes の測定法に準じて 本症例の 歯列弓の 幅径と長径を測定したものである。なお，頓側咬頭頂は $\mathrm{C}_{3}$ で崩壊しているため, 頓側咬頭頂間の中点を代用 した. 本症例の歯列弓の幅径は上顎で $44.0 \mathrm{~mm}$, 下顎で $34.2 \mathrm{~mm}$, また長径は上顎で $34.7 \mathrm{~mm}$, 下顎で $32.8 \mathrm{~mm}$ であった. 大坪や山内らの測定值と比較しても, 本症例 の歯列弓は幅径, 長径ともに正常範囲内にあることが同 える ${ }^{1,2)}$.

$\mathbf{X}$ 線所見：トルコ鞍の形態は不明瞭で, Glabella は突 出し, 下顎角の開大 $\left(138.5^{\circ}\right)$, 下顎骨関節突起長軸方



写真 5 術前側位頭部X線規格写真 Gonial angle $138.5^{\circ}$ で, 下顎骨関 節突起長軸方向の過成長，下顎枝の延 長等下顎前突所見が認められる。

経蝶形骨洞腫瘍切除術あるいは腫瘍の 浸潤破壊のため $\mathrm{S}$ 点が明確でなく，さ らに上下顎の centric stop がないた め，セファロ分析は十分行えなかった。

向の過成長，下顎枝の延長などの下顎前突所見が認めら れた（写真 5 ).

臨床検査所見：血液，尿一般検査に特記すべき異常を 認めず, GH 以外のホルモンの異常分泌, 糖代謝障害や 心肥大の併発を認めなかった。

診 断 : GH 産生下垂体腺腫に伴う下顎前突症および 巨舌症。 
処置および経過：図 1 に示すごとく下垂体腺腫摘出術 後は, 血中 $\mathrm{GH}$ 值は概ね $10 \mathrm{ng} / \mathrm{ml}$ 以下に 20 加月以上 制御され，臨林的に非活動性もしくは活動性の乏しい末 端肥大症と考克られたので，1988年6月日日下買後退衍 の術前処置として, Egyedi Obwegeser法による舌縮小術 を施行した(写真 6).ところが，その 2 か月後血中 GH 值の上界が認められたため，同年 9 月回健和会

病院脳神経外科入院となり，放射線 $40 \mathrm{~Gy}$ 照射および Bromocriptine 内服治療が行われた。血中 $\mathrm{CH}$ 值の制 御は不十分なるのの，上昇傾向はなくやや低下傾向を 示したので，術前の補経処置を施し，1989 年 3 月口日 Obwegeser-Dal Pont 法による下顎後退術を施行した.

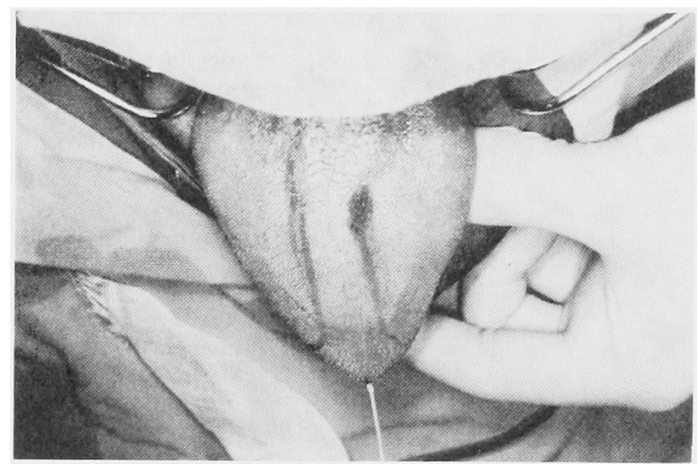

写真 6 Egyedi Obwegeser 法による舌縮小術術中 写真
下顎の前突が著明なため, 解剖学的正常咬合は目標とせ ず，まずは咬合接触の回復に努め，下顥の後退移動量は 正中部で $15 \mathrm{~mm}$ とした。術後は1日間 ICUにて管理 し，数日軽度の呼吸困難と発熱が認めら机たるのの良好 に経過した，枵間固定としては，上下の米雅に Schuchardt の線副子圭装着し結禁線にて術後 45 日間行い, 倾帽を 6 か月間使用した。

写真 7 は術後 3 日目と 7 か月半を経過した側位頭部 X 線規格写真で，後戻りは認められず審美性は著明に改善 Lた.

現在, 術後 1 年 9 か月を経過 乙, 血中 GH 值は 10 $\mathrm{ng} / \mathrm{m} l$ 以下に安定し，顔貌，咬合機能も良好である (写 真 8,9 ).

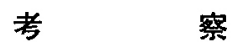

末端肥大症は下垂体前葉からの $\mathrm{GH}$ 分泌過剩によっ て生し，肺癌や膆缄腫瘍などの異所性ホルモン産生腫湯 からの GRF (growth hormone-releasing factor) 分泌 を原因とするごく少数の症例を除さ，大部分は GH 産 生下垂体腺腫による内分泌疾患である゙3.

本邦に拈ける報告例は，昭和49年の厚生省間脳下垂体 機能障害調查研究班の全国集計によると，過去10年間に 約 400 例であり，比較的むれな疾患といえる4?.

GH の過剩分泌が骨端線閉鎖以前に起これば巨人症と なり骨端線閉鎖以後に起これば末端肥大症となるといわ



a

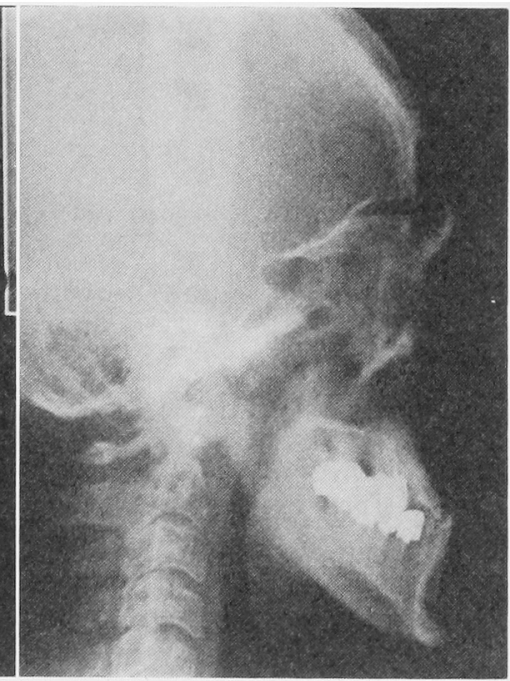

b

写真 7 得後の侧位頭部 $\mathrm{X}$ 線規格写点 後屃り傾向はなく，経過は良好である。

$\mathrm{a}$ ：政後 3 日目，b：術後 7 只半 


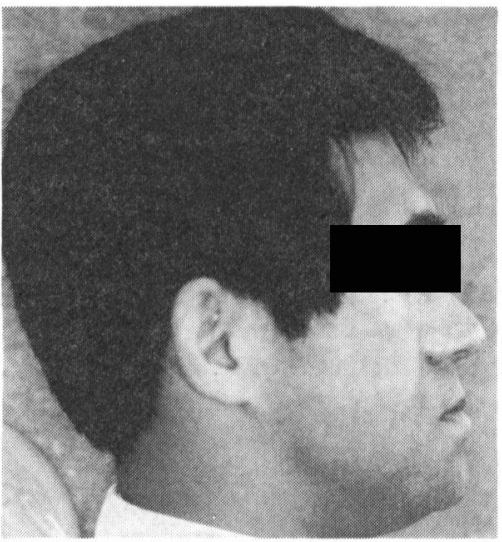

写真 8 術後 1 年 2 か月目の側貌
れている。しかし，巨人症の約 $40 \%$ が本症の特徵を有 し，小児の末端肥大症もあることから，発病の時期的な 差ばかりでなく，体質的要素なども関係しているとさ れ, 最近では両疾患を総括して $\mathrm{GH}$ 過剩症と呼ぶこと が多い ${ }^{5 \sim 7)}$.

本症例の場合, 現病歴から発病は14，5歳頃と考克ら れ，巨人症の様相は呈していない.

$\mathrm{GH}$ の生理作用は,

1）蛋白代謝一細胞内へのアミノ酸取り込久増加, 核 酸蛋白質の生合成の増加.

2) 脂質代謝一脂肪組織の中性脂肪分解.

3) 糖代謝一糖利用の低下, インシュリン捛抗作用.

4) 水, 電解質代謝一体液量の増加, Na, P の貯留.

5 ) 軟骨組織に及ぼす影響—-somatomedin（以下 $\mathrm{Sm}$ と略記）を介しての骨端部軟骨細胞の発育促進。

など多岐にわたり，全身すべての細胞に作用し，標的組 織を有さない7，そのため，本症には種々の症状が出現 してくる ${ }^{3)}$ また, $\mathrm{GH}$ 分泌は通常, 低血糖刺激, 絶 食, 運動, 睡眠, ストレス, FFA 低下, アミノ酸負荷, $\beta$-Blocker, $\alpha$-adrenergic stimulator, estrogen などによ り促進され，逆にブドウ糖負荷，FFA 上昇， $\alpha$-adrenergic blocker, antiserotonin agent などにより抑制され $ろ^{6)}$. 本症例では, 脳神経外科にて治療を受け, 空腹時 血中 $\mathrm{GH}$ 值が $10 \mathrm{ng} / \mathrm{m} l$ 以下飞維持されていたことによ り, 初診時飞未いて末端の肥大, 審美・咀嚼障害以外の 症状は認められなかった。

顎顔面外科処置の時期として理想的には血中 GH 值 が正常化（空腹時で $5 \mathrm{ng} / \mathrm{ml}$ 以下）した後が 望ましい のであるが，本症例のごとく制御不十分な症例も少なく ない, $5,9,10)$

末端肥大症が活動性であるか否かの判断について中 川は安静空腹時血中 $\mathrm{GH}$ 值が $10 \mathrm{ng} / \mathrm{m} l$ 以下で GTT (glucose tolerance test) で血中 GH 值が不変, ITT (insurin tolerance test) で血中 GH 值が不変, ないし

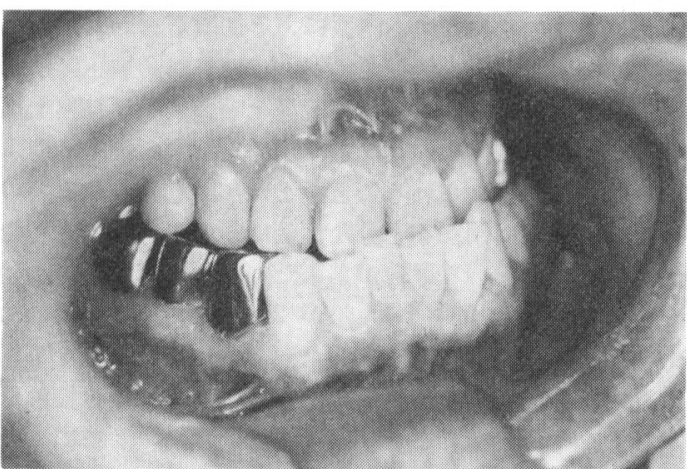

写真 9 術後 1 年 2 か月目の口腔内写真 後戻り傾向はなく，咬合機能孔良好である。

わずかに増加することをあげて挴り，さらに GH の作 用の直接的指標である血中 $\mathrm{Sm}$ (特に $\mathrm{Sm}-\mathrm{C}$ ) 值の測定 をも勧めている ${ }^{11)}$ ．しかし，下垂体腺腫に対する加療 後, 血中 GH 值があまり低下しないのに臨床症状が軽 快したり, 経時的に臨床状態を綿密に観察しても非活動 状態と考えられるにもかかわらず血漿 $\mathrm{Sm}-\mathrm{C}$ 值は高值 を示寸症例もみられ，さら飞 $\mathrm{Sm}-\mathrm{C}$ 值が正常である症 例の中に異常反応の認められるものもあることから，血 中の $\mathrm{GH}$ 值や $\mathrm{Sm}-\mathrm{C}$ 值のみにより本症の活動性を判断 することは早計なようである ${ }^{31}$.

末端肥大症患者に対して買顔面外科処置を施した際の 合併症として，これまで気道障害，肺の閉塞，心筋梗塞 などが報告され，致命的な症例も記録されてきた ${ }^{12 \sim 14) . ~}$ これらの合併症は, 上気道と心蔵血管系の異常に関連し て引き起こされている。つまり，GH とよる口腔・鼻咽 頭特よび喉頭粘膜上皮の肥厚, 舌の肥大, 鼻之喉頭の軟 骨の異常, 声門の狭小化，心肥大括よび 合併する高血

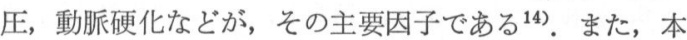
症の $25 \sim 50 \%$ に甲状腺腫が認められ，これも気道障害の 一因となり得るとされている ${ }^{15)}$ 。このような術中・術後 の合併症や後戻りの可能性を考古ると, 顎顔面外科処置 は躊躇させられるところである12,13)

加療により非活動状態となった末端肥大症では，それ までの骨の異常が改善するといらことはまず起こらな いが，軟組織の異常はよ〈改善される ${ }^{16)}$ 。このため, Whelan らは前述の合併症を防ぐ意味に括いて, 術前少 なくとも12〜15か月はできるだけ血中 $\mathrm{GH}$ 值を正常化 することを勧めている14).

本症例では，以上のことを踏ま兄て下垂体腺腫摘出後 21 か月間観察を行い，血中 $\mathrm{GH}$ 值は招拈むね $10 \mathrm{ng} / \mathrm{ml}$ 以下で推移し, 臨床的にも非活動性と考光られたので, 下顎後退術後の後戻りと気道障害の予防をかねて巨舌症 に対し舌縮小術を施行した。 ところが，その 2 か月後よ り血中 GH 值が徐々に上昇し, 残存腫瘍に対する放射 
線治療と bromocriptine 内服による加療が行われたが，

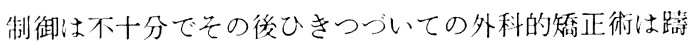
躇させられた。しかし，口腔・身・咽頭・喉頭粘膜上皮 の肥厚や末端肥大の進行などは認められず, 臨床的には 非活動状態と考えられること，また加粉的骨代謝低下の 可能性や過去に制御不十分な症例に対して外科的矯正を 行い成功したといら報告があったこと, さらに患者の強 い希望もあり, 血中 $\mathrm{GH}$ 值が $20 \mathrm{ng} / \mathrm{ml}$ 前後の状態に おいて下顎後退術に踏み切った。本症例においては下買 の前突が著しいため, 下顎後退術によりまず咬合接触を 再建し，その後上䫇の骨切り術あるいは Köle 法により 正常被蓋を棈筑する买定であった。しかし，患者は今回 の手術結果について機能的 - 審美的に十分満足し, 追加 手術を望んでいないことから，当面追加ないし二次的外 科矯正術は子定していない。

ここで，末端肥大症患者の靧顔面外科処误を行う場 合，本症例の経験と過去の文献なとからその手術時期抽 よび注意事項を以下に述べる ${ }^{6,11 ~ 15) . ~}$

1. 術前は脳神経外科あるいは内科的治療により安每 空腹時血中 $\mathrm{GH}$ 值を極力正常值 $(5 \mathrm{ng} / \mathrm{ml}$ 以下) に近 づける（できれば $10 \mathrm{ng} / \mathrm{ml}$ 以下）。

2. GTT, ITT, 血中 Sm-C 佔测定などの活㓰性試験 や足底軟部組織厚 (heel pad thickdness) などの臨床的観 察を行い, 活動性の強い症例については手術を避ける。

3. 前述の活動性試験で非活亚性と確認できた症例で も, 軟組織の減少が期待できるので術前少なくとも1年 以上は経過観察を行ら。

4. 他のホルモン異常を合併している場合は，内科的 制御を十分行5。

5. 術前に気道の精值を行い, 気道の障贵と成し得る ものは除去しておく（たとえば，甲状腙腫，巨舌症など は術前に処罡をしておく).

6. 術後は気道の確保に留意し，できればICUにて 管理を行う。

最後に, GH の制御不十分な症例に対して買顔面外科 処置を施した後，長期にわたって経過钼察を行ったとい ら報告は涉伤し得ず，軽度ではあるが正常值を越える GH が下嚬骨にどのよらな影䅦を及ぼすか與味深いもの があり，本症例では今後長期的钼察を行っていく予定で ある。

\section{結}

語

36 茂男性の IfI中 GH 值が基準值より高い未端肥大症 患者における颜面頭蓋の变形に対し, 外科的矯正術を施 行し, 術後 1 年 9 か月の現在, 䍒美的ならびに機能的再面 において，本人の希望も合わせ良好な結果を得ている。

稿孛終えるにあたりここ指学とご校閲を焬った消水正

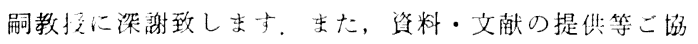

力下さいました本学腷神経外科学教室笠井直人先生に厚 く御礼申し上げます。

な扰, 本論文の要旨は, 第22回日本口腔科学会九州地 方部会（1989<平成 $1>$ 年 12 月 2 日鹿児島）に扣いて口 演した。

\section{引用 文 献}

1) 大坪淳造: 日本人成人正常咬合者の菌冠幅径と 迷列弓及び Basal Arch との関係について。日 矯艘誌 16: 36-46 1957.

2) 山内和夫, 伊藤敬一, 他：日本人青年男女正常

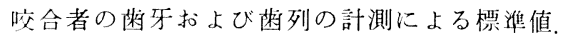
日矯粎誌 $24 ： 1-71965$.

3）魚住徽, 向田一敏：脳下垂体腺腫 2) 成長 ホルモン座生腺腫, 高昏公朋監修: 腷神経外 科シリーズ下垂体部一第三脳室腫瘍, 現代医 療社, 東京, 1989, 105-124頁。

4) 厚生省特定疾患間脳下垂体機能障害調查旺: 昭 和 $49 \sim 57$ 年度総括研究事業報告苫。

5) 奥住微, 大田正博: 視床下部一下垂体の病気 末端肥大症. Clinical Neuroscience 2: 316-318 1984-3.

6）武田成正，戸金隆三，他・成長ホルモン脳神経 外科々の関速で。脳神経外科 8:691-699 1980.

7) 中尼喜久, 山形做一, 他編: 下垂体前葉, 内科 学書( I ), 中山占店, 東京, 1976, 416-423面.

8）藤田佳子, 宮崎三弘, 他: 末端肥大症の 3 例。 日立医会誌 53：1-7 1989 .

9）前田明子, 敛木胎之, 他：外科的矯正治療を適 用した木端肥大症の 1 例。 日矯蒋誌 44：3753871985.

10) Meerloo, R.J.: Surgery in active acromegaly with prognathism and a lateral open bite. Int J Oral Surg 10: 304-308 1981.

11）中川光二: 未端肥大症 - 巨人症; 志田圭三編 : ホルモンと臨床 25 增刊 新内分泌データーブ ック上尞, 医学の世界社, 東宗, 76-79頁。

12) Hamilton, M.K., Hurwitz, G.A., et al.: Treatment of mandibular prognathism in an acromegalic patient. J Oral Surg 34: 366-369 1976.

13) Ross, J.W. Mandibular ostectomy in an acromegalic. Int J Oral Surg 3: 256-260 1974.

14) Whelan, J., Redpath, T., et al.: The medical and anaesthetic management of acromegalic patients undergoing maxillo-facial surgery. $\mathrm{Br}$ J Oral Surg 20: 77-83 1982.

15）川久保篤, 有吉陖一, 他: 甲状腺機能立進症を 合併した末端肥大症の麻酔。麻酔 38：674-678 1989.

16) Tornes K., Gilhuus-moc, O.: Correction of jaw deformities subsequent to treatment of acromegaly. Int J Oral Maxillofac Surg 15: 446-450 1986. 